\section{A Challenge to the Pharmacy Profession to Raise Its Voice on Health Care Reform}

Why do I not hear the voice of the pharmacy profession reacting to congressional efforts to repeal and replace the Affordable Care Act (ACA), given the significant effect that repeal and replace proposals will have in community and institutional pharmacy settings on the access to prescription pharmaceuticals and on the health status of at-risk populations?

Since January 2017, the U.S. Congress has fielded 4 proposals to repeal and replace the ACA: the House's American Health Care Act (AHCA), the Senate's Better Care Reconciliation Act (BCRA), the Senate's Obamacare Repeal Reconciliation Act (ORRA), and, most recently, the Senate's Graham-CassidyHeller-Johnson Amendment to HR 1628 (GCHJ). A side-by-side comparison of the major provisions in these proposals is available at: http://www.aha.org/content/17/aca-ahca-bcra-orragchj-comparison.pdf.

These proposals failed to pass partly because of public outcry and opposition from health care professionals, hospital and insurer associations, and patient advocacy groups and because of critical published reviews. ${ }^{1-3}$ According to a recent $A B C$ News/Washington Post poll, "the public supports Obamacare over the proposed Graham-Cassidy bill by 56-33 percent.".4

In a preliminary analysis of GCHJ, the Congressional Budget Office (CBO) wrote, "The number of people with comprehensive health insurance that covers high-cost medical events would be reduced by millions compared with the baseline projections for each year during the decade, $\mathrm{CBO}$ and JCT [Joint Committee on Taxation] estimate. That number could vary widely depending on how states implemented the legislation, although the direction of the effect is clear."

In a letter to Senators McConnell and Schumer, the American Academy of Actuaries stated, "Unless the funds allocated in the proposal are used to create stable markets by maintaining a level playing field for insurers and achieving a balanced risk pool, GCHJ would likely lead to higher individual market premiums, lower enrollment, eroded protections for those with preexisting conditions, lower insurer participation, and more unstable markets than under current law... The caps would limit federal funding on a per enrollee basis based on inflation rates that are projected to be outpaced by long-term Medicaid costs. In combination, these modifications could result in lower federal financing per (Medicaid) enrollee than is received under current law."

After the failure of GCHJ to pass, the American Nurses Association observed, "As we have seen before, the failure of one repeal and replace proposal does not automatically mean that the healthcare system is safe. It is very likely that the Trump administration will continue to undermine the
ACA through regulatory and other policy measures; we have already seen this in their assaults on value-based purchasing regulations, their brinksmanship with respect to cost-sharing reduction payments, and their refusal to undertake a robust ACA enrollment strategy crucial to connecting Americans with individual health insurance coverage. Senate Republicans are also already discussing language for the FY 2019 budget which would allow them to once again use reconciliation to repeal and replace the ACA."

ACA repeal and replace efforts will continue. I urge pharmacists and the pharmacy profession to raise their voices regarding the effect of health care reform proposals on access to prescription pharmaceuticals.

\section{Elan Rubinstein, PharmD, MPH}

EB Rubinstein Associates

elan.b.rubinstein@gmail.com

\section{DISCLOSURES}

Rubinstein provides consulting services to the pharmaceutical industry, health plans, employers, and specialty pharmacies and is a member of the editorial advisory board of Specialty Pharmacy News. He was a participant on the Amgen Biosimilar Report Advisory Board and reports consulting fees from Amgen.

\section{REFERENCES}

1. Office of Democratic Whip Steny H. Hoyer. Providers, patient and consumer advocates, hospitals, insurers urge GOP to reject latest TrumpCare proposal. September 20, 2017. Available at: http://www.democraticwhip. gov/sites/democraticwhip.house.gov/files/attachments/Organizations $\% 20$ Oppose\%20Senate\%20TrumpCare\%20Bill\%20092017.pdf. Accessed October 24, 2017

2. Adler L, Aaron HJ, Ginsburg PB, Fiedler M. The Graham-Cassidy Planthe most harmful ACA-repeal bill yet. N Engl J Med. 2017;377(16):e23. Epub September 22, 2017. Available at: http://www.nejm.org/doi/pdf/10.1056/ NEJMp1712614. Accessed October 24, 2017.

3. Lueck S. Cassidy-Graham would unravel protections for people with preexisting conditions. Center on Budget and Policy Priorities. September 26, 2017. Available at: https://www.cbpp.org/sites/default/files/atoms/files/9-2617health3.pdf. Accessed October 24, 2017.

4. Langer Research Associates. Public prefers Obamacare to GrahamCassidy, 56-33\%. September 22, 2017. Available at: http://www.langerresearch.com/wp-content/uploads/1191alHealthCare.pdf. Accessed October 24, 2017.

5. Congressional Budget Office. Preliminary analysis of legislation that would replace subsidies for health care with block grants. September 2017. Available at: https://www.cbo.gov/system/files/115th-congress-2017-2018/ costestimate/53126-health.pdf. Accessed October 24, 2017.

6. American Academy of Actuaries. Letter to Senators McConnell and Schumer. September 22, 2017. Available at: http://www.actuary.org/files/ publications/GCHJ_092217.pdf. Accessed October 24, 2017.

7. Craig G. Senate Republican healthcare push ends in defeat (again). Capitol Beat. September 26, 2017. Available at: http://anacapitolbeat.org/2017/09/26/ senate-republican-healthcare-push-ends-in-defeat-again. Accessed October 24, 2017. 